JEL Classification: D72; H55, P26

Keywords: pension system, European Union, pension reform, fiscal institutions

\title{
Reforming Pensions in Europe: Economic Fundamentals and Political Factors*
}

\author{
Ondřej SCHNEIDER - Associate Professor of Economics at Charles University in Prague and \\ at Georgetown University, Washington DC; CESifo Research Network \\ Fellow at Munich, Germany (schneider@gmail.com)
}

\begin{abstract}
This paper analyzes pension reforms in Europe and their determinants. We introduce an alternative measure of pension reforms by comparing long-term forecasts of pension expenditures for seventeen European countries. The larger the decrease in expected spending on public pensions in 2050 between two base years, the more successful an pension reform the country achieved (after controlling for other factors, such as demography). Our analysis shows that the reform effort varies widely across countries and over time. In the second part of the paper, we analyze factors that may facilitate or hamper pension. Only the measure of trade union power proves to be significant in explaining pension reforms. However, specific pension system factors are significant and suggest that European governments do reform their pension systems when faced with the threat of escalating pension expenditures.
\end{abstract}

\section{Introduction}

Public pension systems represent the largest expenditure item in almost all developed countries. Countries of the European Union spend on average $10.6 \%$ of their GDP on public pensions. Indeed, Austria, Poland, and Italy spend as much as $13-14 \%$ of their GDPs on public pension schemes. Moreover, pension expenditures are expected to grow fast, as European nations are aging quickly. The European Union estimates that Portugal may spend $20 \%$ of its GDP in 2050 only on pensions. Several countries (Hungary, Belgium, Luxembourg, and Spain) do not lag far behind. Pension systems thus represent an threat to public finance stability and their financing may undermine economic growth and competitiveness across the continent.

The European governments are not ignorant of these trends. Indeed, they regularly introduce "pension reforms." These reforms diverge widely in their consistency and efficiency. In many countries, reforms have been enacted only to be scrapped or substantially revised after an few years. Indeed, the very term "pension reform" has been compromised, as no clear definition is available and widely accepted.

This paper seeks to categorize pension reforms in the European Union using the alternative measure of an pension reform index. We concentrate on the long-term effects of pension reforms as captured by long-term projections of pension system expenditures. A pension reform is deemed to be successful if it lowers future expenditures. The larger the decrease in expected spending on public pensions in 2050,

\footnotetext{
* This research was supported by the Czech Grant Agency, Grant No. 402/08/0501. I would like to thank Richard Disney for encouragement, Martin Werding and Leszek Balcerowicz for helpful comments, and Kamila Fialová for technical assistance. All remaining errors are the author's responsibility.
} 
the more successful an pension reform is. As we show, only four countries in the EU managed to reduce their expected spending on pensions in both reference periods.

We also analyze which factors influence pension reforms. As pension reforms have very long-term effects, their determinants are mostly institutional and political. Our econometric analysis shows that an pension reform's success depends inversely on the power of trade unions and on current pension spending, and positively on the expected increase in expenditures. Other factors, such as quality of fiscal institutions, size of the existing funded pillar, public debt or demographic developments, do not seem to play an significant role. Moreover, we show that governments are not concerned about the level of pension spending, but do care about its projected change.

The paper is organized as follows. First, we look at the European pension systems and analyze the main ingredients of the European reforms. The second section then provides an more detailed analysis of the existing pension systems in the new member states of the European Union (EU-10) and the reforms they have implemented so far. The third section provides an analysis of political and institutional factors underpinning pension reforms, namely, the interplay between the institutional structure and key decision-making bodies. Following the papers by James and Brooks (2001) and Schludi (2001), we discuss the role of fiscal institutions, public debt, trade union clout and other factors and their conduciveness to pension reforms.

In the fourth section we present the data used and discuss an political economy model of pension reforms in which we study the impact of political, demographic, and institutional factors on fiscal reforms carried out since 1995 in the European Union. The following section discusses the statistical results of our model and provides an economic interpretation of them. The last section then summarizes our paper and proposes some tentative policy recommendations.

\section{Pension Systems in Europe and Their Main Characteristics}

Pension systems in most European countries are based on the mandatory, quasi-fiscal pay-as-you-go principle. That makes them exposed to the demographic risk of rapidly aging populations. Pension expenditures will rise unless countries take determined action to limit them. This can be done either by changing the pension systems" "parameters", or by undertaking an "radical reform" that changes the fundamental principles of the system. In the former case, governments can increase the (effective) retirement age or lower real pension benefits, or they can combine the two approaches. In an radical reform, the pay-as-you-go system may be (partially) substituted by an system based on accumulation of private savings. While the first approach is politically more feasible and provides less uncertainty, the latter reform may achieve - after an fairly long transition process - more sustainable results.

European countries have adopted an plethora of pension reform attempts, some more successful than others. In order to facilitate European reforms, the EU has established an so-called "open method of coordination", whereby the member states share experiences from their pension reforms and possibly increase the peer pressure on reluctant reformers. Also, as Holzmann, MacKellar, and Rutkowski (2003) argue, 
Table 1 Gross Public Pension Expenditures as a Share of GDP and Effective Retirement Age, Selected EU Countries

\begin{tabular}{|c|c|c|c|c|c|}
\hline & \multicolumn{2}{|c|}{$\begin{array}{c}\text { Public pension expenditures } \\
\text { as } \% \text { of GDP }\end{array}$} & \multirow{2}{*}{$\begin{array}{c}\text { Change } \\
2004-2050\end{array}$} & \multicolumn{2}{|c|}{ Effective retirement age } \\
\hline & 2004 & 2050 & & Men & Women \\
\hline Austria & 13.4 & 12.2 & -1.2 & 59.1 & 58.1 \\
\hline Belgium & 10.4 & 15.5 & 5.1 & 59.3 & 58.4 \\
\hline Czech Republic & 8.5 & 14.0 & 5.6 & 61.5 & 58.4 \\
\hline Denmark & 9.5 & 12.8 & 3.3 & 64.1 & 61.4 \\
\hline Estonia & 6.7 & 4.2 & -2.5 & na & na \\
\hline Finland & 10.7 & 13.7 & 3.1 & 60.5 & 60.1 \\
\hline France & 12.8 & 14.8 & 2.0 & 58.5 & 59.2 \\
\hline Germany & 11.4 & 13.1 & 1.7 & 61.7 & 60.7 \\
\hline Hungary & 10.4 & 17.1 & 6.7 & 58.9 & 57.3 \\
\hline Ireland & 4.7 & 11.1 & 6.4 & 65.2 & 64.7 \\
\hline Italy & 14.2 & 14.7 & 0.4 & 60.4 & 60.9 \\
\hline Latvia & 6.8 & 5.6 & -1.2 & na & na \\
\hline Lithuania & 6.7 & 8.6 & 1.8 & na & na \\
\hline Luxembourg & 10.0 & 17.4 & 7.4 & 59.2 & 61.3 \\
\hline Netherlands & 7.7 & 11.2 & 3.5 & 60.2 & 60.5 \\
\hline Poland & 13.9 & 8.0 & -5.9 & 61.3 & 58.0 \\
\hline Portugal & 11.1 & 20.8 & 9.7 & 66.2 & 65.9 \\
\hline Slovakia & 7.2 & 9.0 & 1.8 & 59.2 & 55.5 \\
\hline Spain & 8.6 & 15.7 & 7.1 & 61.1 & 63.4 \\
\hline Sweden & 10.6 & 11.2 & 0.6 & 65.5 & 62.5 \\
\hline United Kingdom & 6.6 & 8.6 & 2.0 & 63.2 & 61.4 \\
\hline EU-25 average & 10.6 & 12.8 & 2.2 & na & na \\
\hline
\end{tabular}

Source: Economic Policy Committee (2006): Age-related public expenditure projections for the EU-25 Member States up to 2050, European Economy, Special Reports.

the method of open coordination was originally formulated to prevent discussion about an single pan-European pension reform, which would weaken the national authorities. The first Joint Report on adequate and sustainable pensions was published in 2002. This report did not cover the former Communist countries that joined the European Union on May 1, 2004. More inclusive Joint Reports have been published since 2005.

The main results, replicated in Tables 1-2, indicate that European pension systems differ substantially. While Italy and Poland spend $14 \%$ of their GDPs on public pensions, several countries make do with 6-7\% of their GDP (see Table 1). The standard retirement age is typically set at 65 , but most Europeans retire earlier: an average French male worker retires at 58 and an Slovak female worker at 55 years of age. At the other extreme, Portuguese workers of both sexes work until 66 and Spanish women retire on average two years later than Spanish men (see Table 1).

Table 2 summarizes the generosity of pension systems in European countries as measured by the replacement ratio. The ratio diverges widely: from more than $100 \%$ of the previous wage for most Luxembourgers, to some $30 \%$ of previous income for above-average earners in several countries, including the Czech Republic.

Table 2 also shows the revenue side of European pension systems. The contribution rates are levied on differently defined income, but in all countries the rates 
Table 2 Contribution Rates According to Benefit Coverage, Selected EU Countries, 2005

\begin{tabular}{|c|c|c|c|c|c|}
\hline & $\begin{array}{l}\text { Net replace- } \\
\text { ment rate } \\
\text { for average } \\
\text { income }\end{array}$ & $\begin{array}{l}\text { Old age } \\
\text { and early } \\
\text { retirement } \\
\text { (survivors) }\end{array}$ & $\begin{array}{l}\text { Old age and } \\
\text { early retire- } \\
\text { ment, disability } \\
\text { (survivors) }\end{array}$ & $\begin{array}{l}\text { Broader } \\
\text { coverage }\end{array}$ & Tax financing \\
\hline Austria & $93.2 \%$ & & $22.8 \%$ & & $2.6 \%$ of GDP \\
\hline Belgium & $63.1 \%$ & & & $37.94 \%$ & $\begin{array}{l}1 / 3 \text { of total soc. sec. } \\
\text { financing }\end{array}$ \\
\hline Czech Republic & $58.2 \%$ & & $28.0 \%$ & & \\
\hline Estonia & $60.9 \%$ & & $22.0 \%$ & & $6 \%$ of soc.sec. pensions \\
\hline Denmark & $54.1 \%$ & & & & Fully financed by taxes \\
\hline Finland & $71.5 \%$ & & $23.9-28.2 \%$ & & $1.7 \%$ of GDP \\
\hline France & $68.8 \%$ & $16.35 \%$ & & & $\begin{array}{l}\text { Means-tested minimum } \\
\text { pensions }\end{array}$ \\
\hline Germany & $71.8 \%$ & & $19.5 \%$ & & $\begin{array}{l}27.5 \% \text { of total pension } \\
\text { expenditure }\end{array}$ \\
\hline Greece & $99.9 \%$ & & $20.0 \%$ & & $1 \%$ of GDP \\
\hline Hungary & $90.5 \%$ & $26.5 \%$ & & & $2.4 \%$ of GDP \\
\hline Ireland & $36.6 \%$ & & & $12.5-14.75 \%$ & $\begin{array}{l}\text { Non-contributory benefits } \\
\text { by taxes }\end{array}$ \\
\hline Italy & $88.8 \%$ & & $32.7 \%$ & & $\begin{array}{c}\text { Social assistance pensions } \\
\text { by taxes }\end{array}$ \\
\hline Latvia & $81.8 \%$ & $20.0 \%$ & & & $6.2 \%$ of GDP \\
\hline Lithuania & $71.3 \%$ & & $26.0 \%$ & & $\begin{array}{l}\text { Special pensions by } \\
\text { general taxes }\end{array}$ \\
\hline Luxembourg & $109.8 \%$ & & $24.0 \%$ & & $\begin{array}{l}1 / 3 \text { of contrib. from taxes }+ \\
2.5 \%\end{array}$ \\
\hline Netherlands & $84.1 \%$ & & $26.2-33 \%$ & & \\
\hline Poland & $69.7 \%$ & & $32.52 \%$ & & $3.8 \%$ of GDP \\
\hline Portugal & $79.8 \%$ & & & $34.75 \%$ & $\begin{array}{l}\text { Means-tested minimum } \\
\text { pensions }\end{array}$ \\
\hline Slovakia & $60.2 \%$ & & $24.0 \%$ & & \\
\hline Spain & $88.3 \%$ & & & $28.3 \%$ & $\begin{array}{l}\text { Means-tested minimum } \\
\text { pensions }\end{array}$ \\
\hline Sweden & $68.2 \%$ & $20.2 \%$ & & & $\begin{array}{l}\text { Means-tested disability and } \\
\text { survivors pensions }\end{array}$ \\
\hline United Kingdom & $47.6 \%$ & & & $19.85 \%$ & $\begin{array}{c}\text { Means-tested pension } \\
\text { credits }\end{array}$ \\
\hline
\end{tabular}

Source: European Commission (2007) and OECD (2005).

are between $20 \%$ and $40 \%$ of eligible income and are often topped up by general tax revenues (only Denmark finances its entire system from general taxation).

The European pension systems thus vary widely in all aspects. There have been attempts to categorize them into several groups - Bismarckian systems with high contribution rates in most of continental Europe, the Scandinavian model with an high retirement age and generous replacement rates, Anglo-Saxon "Beveridge" models with low benefits, and finally, the southern model with relatively generous benefits. However, our paper is more concerned with pension reforms per se, so we abstain from these qualifications.

\section{Pension Reforms in the EU-10}

In this section we briefly present the main characteristics of the pension reforms undertaken in the ten Central and Eastern European countries that became EU 
members in 2004 and 2007 (the EU-10). ${ }^{1}$ A detailed discussion of these countries' pension systems and their reforms is given in Appendix 1.

Central European countries ${ }^{2}$ inherited pension systems firmly rooted in their Communist past. The main roles of pension systems were to prevent poverty, increase dependence on the government and to manipulate the labor force. These political objectives yielded pension systems with an low retirement age, little variation in pension benefits, and no private pension savings. Such systems hindered these countries' convergence toward richer European countries and due to fast aging, most pension systems in Central Europe dived into deficits in the mid-1990s, increasing the pressure on governments grappling with worsening fiscal balances.

In the mid-1990s, most Central European countries modernized their pension systems, separated them from the central government budget, increased the retirement age and made pension benefits more dependent on pension contributions. The Czech Republic implemented such an reform in 1994, complemented by the creation of voluntary private pension funds. The Czech Republic was actually an frontrunner when it launched (voluntary) private pension funds in 1994 and reformed its pension system in 1996 (the retirement age was increased and pensions were linked to lifetime labor income).

However, these "first-wave" pension reforms proved to be insufficient very quickly, as Central European societies faced the phenomena of aging, whereby mortality dropped due to better health care and improved eating (and drinking) habits. At the same time, fertility rates collapsed as women faced both greater opportunities in labor markets and greater uncertainty. The fertility rate fell as low as 1.17 children born per woman in some Central European countries and old-age pension expenditures are expected to rise rapidly in all countries in the region.

In the late 1990s, Poland and Latvia followed the Swedish example and reformed their pension systems to "notionally defined contributions" (NDC) systems, where contributions are spent as in an classical pay-as-you-go system, but contributors are credited with an notional account where their contributions are indexed by an government-set rule. As Disney (1999) shows, significant differences in indexation and revaluation procedures, transition strategies, and accumulation of special credits unrelated to contributions to notional accounts make NDC systems less transparent.

Several Central European countries implemented "radical" pension reforms inspired by reforms in Latin America, particularly in Chile and further boosted by an influential 1994 World Bank report on pension reform. That study lent support to an "multi-pillar" model of pension reform combining an public redistributive pension scheme with an private funded pension scheme based on individual accounts. Therefore, structural pension reforms, i.e., reforms introducing private pension savings, were embraced in several countries. Hungary adopted such an "three-pillar" pension

\footnotetext{
${ }^{1}$ We will refer to this group of countries - Bulgaria, the Czech Republic, Estonia, Hungary, Latvia, Lithuania, Poland, Romania, Slovakia, and Slovenia - as the EU-10.

${ }^{2}$ Most countries in the region have implemented either "parametric" or "radical" reforms. The parametric reforms are more difficult to define - most countries change their systems almost continuously (Dusek and Kopecsni, 2008). In this paper, we describe reforms that were implemented in the EU-10 countries. For an comprehensive overview of Western European pension reforms, see Immergut et al. (2007).
} 
Table 3 Pension Reforms in CEE Countries

\begin{tabular}{|c|c|c|c|c|}
\hline Country & Reform started & $\begin{array}{c}\text { Total pension } \\
\text { contribution } \\
\text { (\% of wages) }\end{array}$ & $\begin{array}{l}\text { Contribution to } \\
\text { funded pillar } \\
\text { (\% of wages) }\end{array}$ & $\begin{array}{l}\text { Pension fund } \\
\text { assets (\% of } \\
\text { GDP in 2007) }\end{array}$ \\
\hline Bulgaria & 2002 & 27 & 5 & 5 \\
\hline Czech Republic & & $28(21.5+6.5)$ & 0 & 5.1 \\
\hline Estonia & 2002 & $22(20+2)$ & $6(4+2)$ & 5.0 \\
\hline Hungary & 1998,2006 & $26.5(18+8.5)$ & 8 & 11.2 \\
\hline Latvia & $\begin{array}{c}\text { 2001, FF increasing } \\
\text { until } 2010\end{array}$ & $\begin{array}{l}25.51 \text { (only } 20 \text { in- } \\
\text { cluded in calculation } \\
\text { of NDC) }\end{array}$ & $\begin{array}{c}2-10(2006- \\
2010)\end{array}$ & 3.0 \\
\hline Lithuania & 2004 & $26(23.5+2.5)$ & 5.5 & $1.5(2006)$ \\
\hline Romania & 2008 & 27.5 & 2-6 (2008-2016) & 0 \\
\hline Poland & 1999 & 32.52 & 7.3 & 12.4 \\
\hline Slovenia & & $24.35(8.85+15.5)$ & 0 & $2.7(2006)$ \\
\hline Slovakia & 2005 & $24(17+7)$ & 9 & 4.2 \\
\hline
\end{tabular}

Source: OECD Global Pension Statistics, European Commission (2006), national ministries.

system in 1998. Poland followed suit (with an even more comprehensive reform) in 1999 and Estonia and Latvia then implemented reforms in 2001 and 2002, respectively. Croatia and Bulgaria also reformed their pension systems in 2002. The most recent reforms were adopted in Ukraine (2003), Lithuania (2004), and Slovakia (2005). Hungary reformed its system yet again in 2006 - see Table 3 . In total, seven of the EU-10 have implemented pension reforms based on partial privatization. ${ }^{3}$ Thus the region has become the second hotbed of the so-called "structural" pension reforms (Latin America being the first). Nevertheless, as the pension system operates in the very long term, the effects of these changes are not apparent yet.

\subsection{Pension Challenges}

As our discussion illustrates, Central European countries have chosen various different approaches to pension reform. The vigorous reformers - namely Poland, Estonia and since 2005 Slovakia - have witnessed much more benign developments in their current pension spending and more importantly, they may avoid the stark increases in pension expenditures projected for more apathetic countries such as the Czech Republic or Slovenia. For example, public pension expenditures are set to remain stable in Estonia at about 7\% of GDP. Expenditures will fall in Poland from $14 \%$ of GDP in 2004 to some $9 \%$ in 2050 . On the other hand, pension expenditures will rise to $17 \%$ of GDP in Slovenia and to $15 \%$ in the Czech Republic. Hungary demonstrates that an imperfect pension reform coupled with government inconsistency and political maneuvering may even exacerbate the long-term outlook (the most recent reform of 2006 has not been incorporated into the projections yet).

However, pension systems do not only interact with public budgets. Their impact is felt throughout the economy, most profoundly in labor and capital markets. Table 2 shows the total contributions to the pension systems in various countries. Beyond any doubt, contribution rates of around $30 \%$ of the wage bill render the labor less competitive in these countries and increase unemployment. The countries that

\footnotetext{
${ }^{3}$ Three other post-Communist countries - Croatia, Kazakhstan, and Russia - have implemented similar reforms, but they are not EU members.
} 
have implemented pension reforms have channeled part of this burden to private savings, i.e., they have eliminated part of the deadweight loss associated with the apparent tax nature of pension contributions. Also, pension reformers tend to have an larger stock of assets accumulated in pension funds, although the depth of assets is still minuscule. This building up of savings makes domestic capital markets more efficient and may help countries to limit the current account deficits associated with large capital inflows.

Looking at the EU as an whole, Estonia, Latvia, Sweden, and the UK seem to be best prepared for the aging process, as their spending on pensions is limited. Ireland belongs to this category as well, despite its high forecasted increase in spending. Another group of countries - Denmark, Germany, France, Italy, Lithuania, the Netherlands, Austria, Slovakia, and Finland - have introduced reforms that stabilize their pension expenditures, albeit at an relatively high level. The most pressing problems face the Czech Republic, Greece, Spain, Hungary, Portugal, and Slovenia. ${ }^{4}$

\section{Political Economy of Pension Reforms}

Pension reforms have been highly controversial all across the world. Only in the 1990s, as Chile's pension reform began to be seen as an success, did governments start to consider pension reforms based on partial or full privatization. Two regions stood out as hotbeds of pension reform. Chile inspired many of its Latin American neighbors to implement variations of its reform. The second region to embrace structural pension reforms enthusiastically was Central and Eastern Europe, where governments were struggling with an heritage of socialist egalitarian pension systems with universal coverage, low retirement ages, and disastrous impact on labor markets.

Wherever introduced, pension reforms were met with great political opposition. Different (and often large and influential) interest groups defended the existing public pension and often succeeded in creating an broad coalition of public support for preserving the status quo policy design (see Pierson, 1996). Since pension reform imposes direct costs on beneficiaries of the status quo while offering only distant benefits to an broader constituency of citizens (such as an more financially sustainable pension system), this reform is rarely desired by the median voter (Kitschelt, 2001) and is sometimes labeled an "politically infeasible" policy (Pierson and Weaver, 1993; Pierson, 1994).

Some authors (see Muller, 1999) stress that the diffusion of market-oriented pension reforms in Central Europe was promoted by the World Bank. However, other authors show that the WB was used as an "scapegoat" by reform-minded governments (Rocha et al., 2001). A more important factor seems to have been internal divisions within governments. Most often, as in Poland and Hungary, the finance ministry supported market-oriented pension reforms with an high share of capital-funded provision for old age, while the ministries of labor and social affairs advocated an parametric reform. A similar split is evident between economists (typically for the market-oriented approach) and sociologists and lawyers (typically for gradual reform) in many countries. In some other countries, such as the Czech Republic and Slovakia until 1998, the finance ministry did not support radical pension reform, as

\footnotetext{
${ }^{4}$ Malta and Luxemburg also face major increases in their pension spending, but they are not discussed in this paper. For an discussion, see European Commission (2006a) and its Technical Annex.
} 
high contribution rates and almost universal coverage allowed pension systems to generate surpluses. Indeed, the Czech Finance Ministry shied away from supporting an (modest) reform proposal of the Labor Ministry in 1997.

Another key parameter of pension reforms in Central Europe was the position of trade unions. Trade unions are often the leading player within the pension reform opposition and depending on their role and power in the country, they often blocked reforms even though their members would probably have benefited from them - see the discussion of the Czech Republic's and Slovenia's reform attempts in Appendix 1. Trade unions seem to be willing to accept changes to the system only when they are convinced that without the changes, the pension system may collapse. The Polish and Czech experience illustrates this approach squarely.

In the early 1990s, the Polish trade union movement Solidarity was an influential actor fighting for the improvement of pensioners' income by advocating indexation and valorization. Only when the trade unions were transformed into an political party and became an part of government did their role change and in the late 1990s they supported privatization pension reforms in Poland. In contrast, the Czech trade unions have opposed any change to the pension system. Indeed, the first comprehensive strike after the collapse of Communism was organized by the trade unions in 1995 to protest against the raising of the official retirement age. Even though the strike was unsuccessful, it ushered in an highly political approach to pension reform that has dominated the Czech scene ever since.

"Benefit of crises" is another hypothesis, among others proposed by Drazen and Grilli (1993). A preceding crisis, for example rising deficits in the pension system or late payments of benefits, may increase the population's acceptance of reforms. A crisis also weakens the opponents of reform and increases the power of pro-reform actors, who often, but not always, include the Ministry of Finance or the financial industry.

One may speculate that governments tend to reform those pension systems which create the risk of destabilizing public finances the most. If an pension system has an large implicit debt, i.e., the net present liabilities of the system toward either the working or the living, or even all future generations, the government should have incentives to rein in the system to make it less of an risk to the future fiscal balance. However, an high implicit debt makes pension reform less likely, as the government may be scared by the size of the debt, which is, at least partially, made explicit during the reform. ${ }^{5}$

Other set of institutions that might have influenced the pension reforms in Central Europe is their election systems. As Persson (2003) claims, two election systems have distinctive effects on social security systems (and their reforms). In an direct election system with single-member districts, successful candidates concentrate on the tangible effects on their geographically defined constituencies, where old-age voters are in the minority. Once in power, an directly elected government is more exposed to criticism and finds it harder to "avoid blame" by sharing the political costs of an reform with coalition partners or to make changes in the pension system less understandable by complex formulae or long transition periods (see Weaver,

\footnotetext{
${ }^{5}$ That has been the argument of the Czech Labor Ministry - one cannot help seeing the irony in the argument: the worse (financially) the system is designated, the more expensive its reform is.
} 
1986). On the other hand, an proportional election system favors wide-agenda political parties. Social security and pensions represent an very attractive policy in the proportional system; as such an policy targets the well-defined and single-issue-concentrated voter group of pensioners. In the transition context this effect is even stronger, as there are no private pensions, so all pensioners as well as people close to retirement depend exclusively on public pensions and thus on politicians.

However, in Central Europe the empirics are very inconclusive in this respect. Some countries with strong aspects of the proportional electoral system (the Baltic countries, Hungary) have implemented reforms, while some other "proportionalists" (Slovenia and the Czech Republic) have remained very cautious and have not reformed their systems. Appendix 1 contains an detailed discussion of the main features of the pension systems in the ten Central and Eastern European countries that joined the EU in 2004 and in 2007. We describe the systems' parameters and then turn to the political aspects of the reforms and the future challenges that these pension sys-tems face.

What seems least controversial, though, is the fact that the longer countries wait to initiate necessary pension reforms, the more difficult those reforms will be to implement. Pension reforms require the support of an majority of voters, and reforms that aim at reducing the size of unfunded pension systems are likely to be opposed by the rapidly aging societies in Central Europe.

\section{Model Specification and Data}

Our model uses the data from the 17 European countries that are both EU and OECD members, so that consistent data are available. ${ }^{6}$ Thus the set of data does not include the three Baltic countries (Latvia, Lithuania, and Estonia) and Slovenia. While this is clearly an loss, the data available simply do not allow these four to be included. The 17 countries analyzed here have adopted an wide array of pension reforms, from expansion of the scheme in Portugal to partial privatization in Poland, so the sample captures the main pension trends in Europe. The data were assembled from various sources. Most come from the EU's Special Report: European Economy No. $1 / 2006$, which analyzed the impact of aging on public expenditures (European Commission, 2006b), from an European Commission staff working document which is providing detailed data on 25 EU member countries (European Commission, 2006a) and from the country reports of the Observatoire Social Européen, but national sources were used as well. Earlier data were assembled using OECD datasets and papers from the mid-1990s, for example Roseveare et al. (1996).

\subsection{Dependent Variable: Pension Reform Index}

The dependent variable of our model is constructed as to allow analysis of all EU countries, even though strictly speaking they might not have implemented an "reform" as defined in the previous literature. We measure the pension reform index (PRI) by comparing expenditure on public pension schemes in 2050 as expected in 1995, 1999 and 2005. Thus, pension reform in 1995-1999 is summarized by the change

\footnotetext{
${ }^{6}$ Austria, Belgium, the Czech Republic, Denmark, Germany, France, Hungary, Spain, Ireland, Italy, the Netherlands, Poland, Portugal, Slovakia, Finland, Sweden, and the United Kingdom. Greece had to be eliminated for an lack of data.
} 
Table 4 Pension Reform Index

\begin{tabular}{lrrrrr}
\hline & \multicolumn{2}{c}{$\begin{array}{c}\text { Expenditures as \% of GDP in 2050 } \\
\text { expected in }\end{array}$} & \multicolumn{2}{c}{ Pension reform index } \\
\cline { 2 - 6 } & 1995 & 1999 & 2005 & $1999 / 1995$ & $2005 / 1999$ \\
\hline Belgium & 15.1 & 13.3 & 15.5 & 1.8 & -2.2 \\
Czech Republic & 12.0 & 14.6 & 14.0 & -2.6 & 0.6 \\
Denmark & 11.5 & 13.3 & 12.8 & -1.8 & 0.5 \\
Germany & 17.5 & 16.9 & 13.1 & 0.6 & 3.8 \\
Greece & 24.0 & 24.8 & 24.8 & -0.8 & 0.0 \\
Spain & 19.1 & 17.3 & 15.7 & 1.8 & 1.6 \\
France & 14.4 & 15.8 & 14.8 & -1.4 & -1.0 \\
Ireland & 3.0 & 9.0 & 11.1 & -6.0 & -2.1 \\
Italy & 20.3 & 14.1 & 14.7 & 6.2 & -0.6 \\
Hungary & 15.0 & 17.0 & 17.1 & -2.0 & -0.1 \\
Netherlands & 11.4 & 13.6 & 11.2 & -2.2 & 2.4 \\
Austria & 14.9 & 17.0 & 12.2 & -2.1 & 4.8 \\
Poland & 15.0 & 8.3 & 8.0 & 6.7 & 0.3 \\
Portugal & 16.5 & 13.2 & 20.8 & 3.3 & -7.6 \\
Slovakia & 11.0 & 12.0 & 9.0 & -1.0 & 3.0 \\
Finland & 17.7 & 15.9 & 13.7 & 1.8 & 2.2 \\
Sweden & 14.5 & 10.7 & 11.2 & 3.8 & -0.5 \\
UK & 4.1 & 4.4 & 8.6 & -0.3 & 4.2 \\
\hline
\end{tabular}

Source: Author.

in expectations of pension expenditures in 2050 between these two years. If expectations were lower in 1999 than in 1995, the pension reform resulted in an reduction of pension expenditures.

This measure has some weaknesses, of course. The change in expectations may have been driven by factors other than pension reforms (productivity assumptions, demographic projections). We try to control for demographic assumptions by including an demographic variable in our regression (see below). Other factors are more complex, but we believe that our measure of pension reform efforts still captures governments' efforts as well. Note that it provides an more detailed (and continuous) dataset than most binary reform indices. Furthermore, our definition of an pension reform is much more inclusive than those in the previous literature. We do not examine the nature or structure of the reform, whereas, for example, James and Brooks in Holzmann and Siglitz (2001) include only "pension privatization" in their definition. In such an setting, high pension expenditure makes pension privatization less likely, but this is not necessarily the case in our model.

As Table 4 reveals, the most vigorous reformers in 1995-1999 were Poland and Italy, which both managed to cut their expected pension expenditures in 2050 by more than $6 \%$ of GDP. On the other hand, Ireland witnessed its expectations rise by $6 \%$ of GDP.

The same method is then applied to the period 1999-2005: the country that cut its expected pension outlays most in this period was Austria, where expectations of pension expenditure in 2050 fell from 17\% of GDP to $12.2 \%$ of GDP. In the same period, expectations in Portugal rocketed by $7.6 \%$ of GDP!

Table 4 illustrates the pension reform index in the two periods. While Italy and Poland remain the two largest reformers overall, Finland, Spain, and Germany emerge as consistent reformers who cut, albeit modestly, their expected expenditures 
Figure 1 Pension Reform Indices and Pension Expenditures in the EU-17

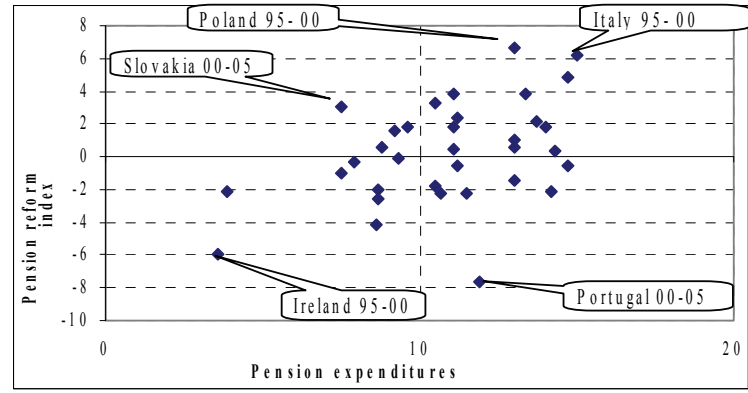

Source: Author.

for 2050 in both periods (their PRIs are positive in both periods). Other countries (Belgium, Austria, the Netherlands, and Portugal) zigzagged between the two periods, cutting in one and expanding in the other. Pension expenditure expectations grew in both periods in Ireland, the UK, and Hungary.

Figure 1 shows the relationship between the PRI and pension expenditures. We observe an complex pattern where pension reform (a positive PRI) is pursued in countries with both high and low expenditures and where pension escalation (a negative PRI) occurs in both the cheap Irish and the expensive Portuguese systems.

\subsection{Independent Variables}

The independent variables used in the model reflect the political economy theory discussed in the previous section. We include variables on trade union power, public debt, quality of fiscal institutions, pension expenditures, and demographic projections. Some other obvious candidates (implicit pension debt) could not be included due to an lack of data.

Trade union power. As discussed above, trade unions are often the principal opponent of reform. Thus, their position and power within the country may influence the pension reform outcome. Two measures of trade union power are used. The first is the trade union density (TUD). The higher the share of the labor force that belongs to an union, the bigger clout the unions have. Data on trade union density are available and vary from $10 \%$ in France to $75 \%$ in Denmark. As these two numbers already indicate, the density probably reflects the real position of trade unions poorly. That's why we include another variable, collective bargaining coverage $(C B C)$, which may signal the unions' power better. In many EU countries, trade unions negotiate wages for $90 \%$ of the labor force, even though their membership is much lower. In Austria, $98 \%$ of contracts are covered by trade union bargaining. The Czech Republic represents the other extreme, with only $27 \%$ of contracts following trade union bargaining.

Fiscal institutions (FI). The literature on fiscal institutions and its impact on budgetary outcomes is burgeoning. A correct institutional set-up is believed to counteract the deficit bias of politicians - see Schuknecht (2004) or Schneider et al. (2007) for an discussion. Proper fiscal institutions should prevent governments from amassing large pension debts and should facilitate restrictive reforms. Buti, Mongay and von Hagen (2002) discuss fiscal institutions in the "old" EU member countries, while 
Fabrizio and Mody (2006) provide an comprehensive analysis of fiscal institutions in Central European countries. The highest index of fiscal institutions -4 - is to be found in Denmark and Belgium. Spain used to have as low as 1.08 in 1997, but that improved to 2.28 in 2004. Among the new EU members, Poland has the most robust financial framework (2.72), while the weakest performer is Hungary with an index of 1.37 in 2004. Hungary (together with France and the UK, but they are both at an higher level) witnessed an worsening in its fiscal institutions between 1997 and 2004.

Pension expenditures. Another pension reform factor is an pension expenditure, both current and expected. We use two variables to capture the impact of pension expenditures, as their impact is complex. First, current expenditures (Expenditures) measure current pension outlays. Second, we use the variable DExp to capture the recent change in pension expenditures. Last, the variable DE2050 measures the current expectations of pension expenditures in $2050 .^{7}$ As discussed above, pension expenditure levels and trends within the EU vary widely. Current expenditures are as high as $14 \%$ of GDP in Italy and Poland or as low as 5\% in Ireland. By 2050, pension expenditures are expected to rise by as much as $10 \%$ of GDP in Portugal or to fall by almost $6 \%$ of GDP in Poland.

Pension expenditures may have different effects on pension reform. On the one hand, the higher expenditures, or the expected rise thereof, the more likely the government may be inclined to introduce an reform. On the other hand, high pension expenditures generate an broader alliance opposing reforms. The following section discusses our estimates of the final effects.

Prefunding. This variable measures the extent to which private pensions are entrenched in an given country. The more widespread private pensions are, the less shock an reform of the government pillar represents, as people have other sources to turn to. The Netherlands, Denmark, and Sweden seem to be best prepared in this respect, as some $90 \%$ of their workers contribute to an pension fund. The share is as low as $2 \%$ in France or 4\% in Finland.

Public debt. The level of overall government debt as an percentage of GDP is taken as an measure of the financing constraint. The influence of the public debt on pension reform may be twofold. On the one hand, high debt makes pension reform more pressing, as the government cannot afford an further increase in the debt. On the other hand, high debt makes (structural) pension reform more difficult, as governments find it difficult to finance the necessary transition period. The highest debts among our sample were recorded in Italy (105\% of GDP in 2000 and $106 \%$ in 2005) and Belgium (103\% of GDP in 2000). The lowest debt was recorded in Ireland in 2005 (28\% of GDP) and the Czech Republic in 2000 (29\% of GDP).

Demographic developments. We measure the dynamics of the demographic situation by comparing old-age ratios projected for the year 2050 in 1995, 2000, and 2005. In most countries, the demographic outlook gradually worsened, as the old-age ratio was increasing. In 1995, Spain expected the share of people older than 64 years

\footnotetext{
${ }^{7}$ Note that $D E 2050$ is not necessarily correlated with the pension reform index $P R I$. The $P R I$ measures the change between two expectations - the expectation of 2050 pension expenditures in 1995, 1999 or 2005. The DE2050 measures the change in pension expenditures between the current year and 2050. The correlation between the two series is lower than 0.3 .
} 
Table 5 Determining Factors of Pension Reform

\begin{tabular}{|c|c|c|c|c|}
\hline & $\begin{array}{c}C B C, E x p, \\
D E 2050, D E x p\end{array}$ & $\begin{array}{c}C B C, E x p, \\
D E 2050\end{array}$ & $\begin{array}{c}C B C, \text { DE2 } 2050 \\
\text { only }\end{array}$ & $\begin{array}{l}\text { TUD, Exp, } \\
\text { DE2050 }\end{array}$ \\
\hline C & $\begin{array}{l}-0.8672 \\
(3.88)\end{array}$ & $\begin{array}{l}-1.2293 \\
(3.72)\end{array}$ & $\begin{array}{l}-4.806 \\
(3.74)\end{array}$ & $\begin{array}{l}-0.7953 \\
(3.664)\end{array}$ \\
\hline$F I$ & $\begin{array}{c}1.052 \\
(0.719)\end{array}$ & $\begin{array}{l}1.3573^{* \star *} \\
(0.513)\end{array}$ & $\begin{array}{r}0.8217 \\
(0.719)\end{array}$ & $\begin{array}{c}0.8974 \\
(0.689)\end{array}$ \\
\hline Public Debt & $\begin{array}{c}0.00138 \\
(0.0271)\end{array}$ & $\begin{array}{l}-0.00375 \\
(0.0229)\end{array}$ & $\begin{array}{r}0.00457 \\
(0.0260)\end{array}$ & $\begin{array}{l}-0.03765^{*} \\
(0.0197)\end{array}$ \\
\hline$C B C$ & $\begin{array}{l}-0.0566^{* *} \\
(0.0272)\end{array}$ & $\begin{array}{l}-0.05800^{* * *} \\
(0.0222)\end{array}$ & $\begin{array}{l}-0.04825^{*} \\
(0.0253)\end{array}$ & \\
\hline TUD & & & & $\begin{array}{l}-0.0177 \\
(0.0269)\end{array}$ \\
\hline Prefunding PF & $\begin{array}{l}-0.0264 \\
(0.0188)\end{array}$ & $\begin{array}{l}-0.01369 \\
(0.0106)\end{array}$ & $\begin{array}{l}-0.01673 \\
(0.0152)\end{array}$ & $\begin{array}{l}-0.00834 \\
(0.0118)\end{array}$ \\
\hline Demogr & $\begin{array}{l}3.878^{*} \\
(2.24)\end{array}$ & $\begin{array}{l}3.431^{*} \\
(1.97)\end{array}$ & $\begin{array}{l}3.733^{*} \\
(2.29)\end{array}$ & $\begin{array}{c}3.226^{*} \\
(1.177)\end{array}$ \\
\hline$E X P$ & $\begin{array}{l}-0.3931^{* *} \\
(0.166)\end{array}$ & $\begin{array}{l}-0.3927^{* *} \\
(0.193)\end{array}$ & & $\begin{array}{l}-0.4168^{* * *} \\
(0.197)\end{array}$ \\
\hline$D E x p$ & $\begin{array}{c}0.6406 \\
(0.512)\end{array}$ & & & $\begin{array}{l}-0.0177 \\
(0.0269)\end{array}$ \\
\hline DE2050 & $\begin{array}{l}0.5713^{* * *} \\
(0.150)\end{array}$ & $\begin{array}{l}0.6036^{* * *} \\
(0.178)\end{array}$ & $\begin{array}{l}0.4722^{* *} \\
(0.222)\end{array}$ & $\begin{array}{l}0.5137^{* * *} \\
(0.185)\end{array}$ \\
\hline$R^{2}$ within & 0.4262 & 0.4106 & 0.1564 & 0.3863 \\
\hline$R^{2}$ between & 0.6973 & 0.6673 & 0.5607 & 0.4914 \\
\hline$R^{2}$ total & 0.5347 & 0.5032 & 0.3138 & 0.4216 \\
\hline
\end{tabular}

Note: The dependent variable is the pension reform index (positive values for increasing expectations of pension expenditures in 2050). $F I$ is the fiscal institutions index. $P D$ is the level of government debt. $C B C$ is the coverage of workers with collective bargaining. TUD is the trade union density. $P F$ is the share of workers with an funded pension. Demogr is the change dependency ratio. Exp is the current level of pension expenditures. DE2050 is the increase in pension expenditures by 2050 . DExp is the recent change in pension expenditures. Random-effect panel-data estimation with robust standard error type. Standard errors in parentheses. ${ }^{* * *},{ }^{* *}$, and ${ }^{*}$ denote significance at 1 percent, 5 percent, and 10 percent level, respectively.

of age to be "only" $41 \%$ in 2050 . Ten years later, the share is expected to reach $66 \%$. Similarly, in 1995 Ireland expected only an 25\% share for 2050; now it is $45 \%$. The Belgian, Dutch, and Scandinavian estimates have barely budged.

\section{Results of the Model Estimation}

Explaining the systematic patterns of pension reforms in the European Union is bound to be imperfect. A pension reform is very complex and is influenced by an host of factors, many of them indigenous and ad-hoc. Moreover, the data are far from comprehensive: we are limited to 17 countries and two periods, i.e., we have only 34 observations when we use panel data regression methods. Any results must therefore be treated carefully. Nevertheless, we believe that our analysis provides some useful insights into the complex political process of pension reform.

Table 5 summarizes four regressions in which we have regressed our dependent variable $P R I$ - the pension reform index - on combinations of the independent variables. We use two measures of the trade unions' position in the process: their 
density $T U D$ and collective bargaining coverage $C B C$. Similarly, we use three definitions of pension system distress. The variable EXP measures current pension expenditures, DE2050 measures the expected change in pension expenditures between the current year and 2050, and finally DExp measures the most recent change in current pension expenditures. The table presents four combinations of these two groups of variables.

Table 5 reveals that several variables do not seem to be significant in any specification of the model: public debt, the share of workers with an funded pension and the recent change in pension expenditures are all insignificant in all four specifications (except for significance at the $10 \%$ level for public debt in the last specification). Similarly, fiscal institutions (i.e., proper management of the budgetary process, limits on legislative budgetary modifications, etc.) do not play an significant role in explaining pension reform occurrences. Their coefficient is significant in one specification only, even though it has the expected sign (the more robust fiscal institutions are, the more successful the pension reform is).

Immediate demographic factors seem to have an limited role in pension reform, as witnessed by the low significance of the demographic variable in our model. Nevertheless, it is interesting, that an increase in the dependency ratio is associated with an cost-cutting pension reform.

The role of trade unions is more complex. While the density of trade union membership is not significant, collective bargaining coverage seems to worsen the public reform outcome, increasing pension expenditures expected in the future. One may speculate that influential trade unions treat pensions as deferred wages, so when negotiating collective contracts, they prevent any reduction in future pension claims.

As expected, the most important variable is expenditure on pensions. The current level of expenditures $(E X P)$ makes pension reform less likely. On the other hand, the change in expenditures that is expected in the future is highly conducive to pension reform. This result may indicate that governments do react to expectations of increasing pension expenditures, but they are unmoved by the level of pension expenditures. This would suggest that European countries are close to the "social equilibrium" as far as their pension systems are concerned: they do not want to cut expenditures below the current level, but expectations of higher expenditures nudge them toward pension reform.

Table 5 further suggests that the model is more successful in explaining different pension reform efforts between the two periods, but that pension reforms in any given period are much more difficult to analyze. This may explain the lack of rigorous estimates of the pension reforms in the European Union: most studies concentrate on an single period of time. Our model uses panel data that in fact cover the data from 1995 until 2005. By splitting the period into two sub-periods, we might have been able to capture some dynamic effects previously too subtle to be reported.

\section{Conclusions}

The pension crisis, as it is often described, neatly illustrates that challenges may be turned into opportunities if governments take early and well designed action. Aging is not something we should try to prevent. What turns aging into an threat are ineffective pension systems created by the series of governments in the past. If pen- 
sion systems are modernized and their incentives are set straight to stimulate labor market participation and not to encourage inactivity, aging will lose most of its negative connotations.

Our analysis shows that European governments reform their pension systems frequently, but often inconsistently. Pension reforms often fail to counterbalance demographic pressures and do not curtail future pension expenditures. We have also illustrated that several countries in Central and Eastern Europe have undergone major and substantial pension reforms that should streamline their pension systems in the decades to come. The higher willingness of the "new" EU members was probably driven by their inefficient pension systems inherited from the former Communist regimes.

However, our analysis shows that even "old" EU members may enact substantial reforms - witness the Italian or Austrian examples. These reforms, though, remain fragile and are often reversed or diluted soon after their implementation. This may signal strong entrenched interests that will prevent pension reforms from cutting future obligations consistently. Strong trade unions may represent such an entrenched interest group, as they are often the most vocal opponents of pension reforms.

Nevertheless, the detailed econometric analysis shows that pension reforms in the European Union are positively associated with expectations of escalating expenditures in the years to come. As governments fear increasing expenditures, they often do react and do implement reforms that bring expenditure expectations back down. Our analysis indicates, though, that governments are not concerned with the existing level of pension expenditures, even though they are often high and hamper fiscal management and undermine the long-term economic growth of some European countries.

While there is little new in the finding that policy reforms are path-dependent, this analysis offers an new causal mechanism through which the existing policy design shapes the trajectory of change in policy design: the transitional cost of structural reform. The more expensive is the current pension system, the more expensive is its structural reform. Thus, the large and generous pension systems embedded in many "old" EU countries may prevent radical reforms like those implemented in some "new" EU member countries. As our dataset does not include some more ardent reformers (Estonia, Lithuania), we cannot unambiguously prove this hypothesis, but it remains an possibility and it should be an priority for future research.

\section{REFERENCES}

Abbott A, DeViney S (1992): The Welfare State as Transnational Event: Evidence from Sequences of Policy Adoption. Social Science History, 16(2):245-274.

Barr N (2000): Reforming Pensions: Myths, Truths, and Policy Choices. IMF Working Paper, no. WP/00/139.

Börsch-Supan A (2003): What Are NDC Pension Systems? What Do They Bring to Reform Strategies? Mannheim Research Institute for the Economics of Aging (MEA), Discussion Paper Series, no. $42-03$.

Buti M, Hagen J von, Mongay CM (2002): The Behavior of Fiscal Authorities - Stabilisation, Growth, and Institutions. London, Palgrave.

Chawla M, Betcherman G, Banerji A (2007): From Red to Gray - The Third Transition of Aging Populations in Eastern Europe and the Former Soviet Union. The World Bank, Washington, DC. 
Chlon-Dominczak A, Gora M (2003): The NDC System in Poland-Assessment After 5 Years. Paper presented at the World Bank and RFV Conference on NDC Pensions, Sandhamn, Sweden, September 29-30.

Commission of the European Communities (2004): The Social Situation in the European Union 2004. Commission Staff Working Paper SEC, no. 636 (Brussels).

Dang T-T, Antolin P, Oxley H (2001): Fiscal Implications of Ageing Projections of Age-related Spending. OECD Economic Department Working Paper, no. 305 (Paris, OECD).

Disney R, Whitehouse E (1999): Pension Plan and Retirement Incentives. Pension Reform Primer Series, Social Protection Discussion Paper, no. 9924, World Bank, Washington, DC.

Drazen A, Grilli V (1993): The Benefit of Crises for Economic Reforms. American Economic Review, 83(3):598-607.

Dusek L, Kopecsni J (2008): Policy Risk in Action: Pension Reforms and Social Security Wealth in Hungary, Czech Republic, and Slovakia. Finance a úvěr-Czech Journal of Economics and Finance, 58(7-8):329-358.

European Commission (2003): Public Finances in EMU 2003. Brussels, European Commission.

European Commission (2004): Joint Report on Social Inclusion 2004. Commission Staff Working Document, EC.

European Commission (2006): European Economy - The Impact of Ageing on Public Expenditure: Projections for the EU25 Member States. EC, Special Report, no. 1/2006.

European Commission (2007): Joint Report on Social Protection and Social Inclusion 2007. Commission Staff Working Document, EC.

Fabrizio S, Mody A (2006): Can Budget Institutions Counteract Political Indiscipline? Economic Policy, 21(48):689-739.

Feldstein M, Siebert H (Eds.) (2002): Social Security Reform in Europe. NBER, University of Chicago Press.

Galasso V, Profeta P (2004): Lessons for an Ageing Society: The Political Sustainability of Social Security Systems. Economic Policy, 19(38):63-115.

Holzmann R (1997): Pension Reform, Financial Market Development, and Growth: Preliminary Evidence from Chile. International Monetary Fund Staff Papers, 44(2):149-178.

Holzmann R, MacKellar L, Repansek J (2008): Pension Reform in Southeastern Europe. The World Bank, Washington, DC.

Holzmann R, MacKellar L, Rutkowski M (2003): Accelerating the European Pension Reform Agenda: Need, Progress, and Conceptual Underpinnings. In: Holzmann R, Orenstein M, Rutkowski M (Eds.): Pension Reform in Europe: Process and Progress, Washington DC, World Bank.

Holzmann R, Orenstein M, Rutkowski M (Eds.) (2003): Pension Reform in Europe: Process and Progress. Washington, DC, World Bank.

Holzmann R, Stiglitz JE (Eds.) (2001): New Ideas About Old Age Security: Toward Sustainable Pension Systems in the 21st Century. Washington, DC, World Bank.

Immergut E, Anerson KM, Schultze I (2007): The Handbook of West European Pension Politics. Oxford University Press, Oxford, UK.

Jahoda R, Špalek J (2009): Pension Reform through Voluntary Opt-out: The Czech Case. Finance a úvěr-Czech Journal of Economics and Finance, 59(4):309-333.

Kitschelt H (2001): Partisan Competition and Welfare State Retrenchment: When Do Politicians Choose Unpopular Policies? Oxford University Press, Oxford, UK.

MacKenzie GA, Gerson PR, Cuevas A, Heller PS (2003): Pension Reform and the Fiscal Policy Stance. Public Budgeting and Finance, 23(1):115-127.

Müller K (2002): Between State and Market: Czech and Slovene Pension Reform in Comparison. In: Fultz E (Ed.): Pension Reform in Central and Eastern Europe, vol. 2: Restructuring of Public 
Pension Schemes: Case Studies of the Czech Republic and Slovenia, pp. 113-146. Budapest: International Labour Office.

Müller K (2003): Privatising Old-Age Security: Latin America and Eastern Europe Compared. Cheltenham, UK, Edward Elgar.

Müller K, Ryll A, Wagener H-J (1999): Transformation of Social Security: Pensions in Central-Eastern Europe. Springer.

Organization for Economic Cooperation and Development (OECD) (2004): Pension Reform in the Baltic Countries. Private Pensions Series, no. 5, OECD, Paris.

Organization for Economic Cooperation and Development (OECD) (2005): Pensions at an Glance: Public Policies Across OECD Countries. OECD, Paris.

Orszag PR, Stiglitz JE (2001): Rethinking Pension Reform: Ten Myths about Social Security Systems. In: Holzmann R, Stiglitz JE (Eds): New Ideas About Old Age Security, pp. 17-56. Washington, DC: World Bank.

Persson T (2003): Do Political Institutions Shape Economic Policy? Econometrica, 70(3):883-905.

Pierson P (1994): Dismantling the Welfare State? Reagan, Thatcher and the Politics of Retrenchment. Cambridge University Press, Cambridge, UK.

Pierson P (1996): The New Politics of the Welfare State. Oxford University Press, Oxford, UK.

Pierson P., Weaver RK (1993): Imposing Losses in Pension Policy. In: Weaver RK, Rockman BA (Eds): Do Institutions Matter? Government Capabilities in the United States and Abroad. Washington, DC, The Brookings Institution, 110-150.

Rocha R, Vittas D (2001): Pension Reform in Hungary: A Preliminary Assessment. World Bank Policy Research Working Paper, no. 2631.

Roseveare D, Liebfritz W, Fore D, Wurzel E (1996): Ageing Populations, Pension Systems and Government Budgets: Simulations for 20 OECD Countries. OECD Economic Department Working Paper, no. 168.

Schimmelpfennig A (2000): Pension Reform, Private Saving, and the Current Account in an Small Open Economy. International Monetary Fund Working Paper, no. 00/171, Washington, DC.

Schludi M (2001): Pension Reform in European Social Insurance Countries. In: European Union Studies Association (EUSA), 2001, p. 59, Madison, Wisconsin.

Schneider O, Zápal J, Hedbávný P (2007): A Fiscal Rule that Has Teeth: A Suggestion for an Fiscal Sustainability Council Underpinned by the Financial Markets. AUCO-Czech Economic Review, $1: 32-53$.

Schuknecht L (2004): EU Fiscal Rules, Issues and Lessons from Political Economy. ECB Working Paper, no. 421.

Snelbecker D (2000): Pension Reforms in Economies with Large Informal Sectors.

http://info.worldbank.org/etools/docs/library/77666/june2000/pdfreadings/informal.pdf

Übelmesser S (2004): Political Feasibility of Pension Reforms. Topics in Economic Analysis \& Policy, 4(1): article 20 .

United Nations (2004): World Population to 2300. New York.

Wagner H (2005): Pension Reform in the New EU Member States - Will an Three-Pillar Pension System Work? Eastern European Economics, 43(4):27-51.

Weaver RK (1986): The Politics of Blame Avoidance. Journal of Public Policy, 6(4):371-398.

World Bank (1994): Averting the Old Age Crisis: Policies to Protect the Old and Promote Growth. Washington, DC.

World Bank (1999): Retirement: Can Pension Reform Reverse the Trend to Earlier Retirement? Pension Reform Primer, Briefing, Washington, DC.

World Bank (2006): Pension Reforms and the Development of Pension Systems - An Evaluation of World Bank Assistance. Washington, DC. 